\title{
Enacting the Absent State : State-formation on the oil-palm frontier of Pomio (Papua New Guinea)
}

\section{Tammisto, Tuomas Aku Wiljami}

2016

Tammisto , T A W 2016 , ' Enacting the Absent State : State-formation on the oil-palm frontier of Pomio (Papua New Guinea) ' , Paideuma: Mitteilungen zur Kulturkunde , no. 62 , pp. 51-68.

http://hdl.handle.net/10138/168453

publishedVersion

Downloaded from Helda, University of Helsinki institutional repository.

This is an electronic reprint of the original article.

This reprint may differ from the original in pagination and typographic detail.

Please cite the original version. 


\title{
ENACTING THE ABSENT STATE \\ State-formation on the oil-palm frontier of Pomio (Papua New Guinea)*
}

\author{
Tuomas Tammisto
}

ABSTRACT. In this article I examine the relationship between new oil-palm plantations and state-formation in Pomio, a remote rural district of East New Britain Province (Papua New Guinea). I am particularly interested in the kinds of spaces of governance produced by the new oil-palm plantations and how this contributes to state formation and territorialisation in Pomio. Plantations in Pomio do not became state-like spaces as a result of top-down processes alone, but also because of active worker initiatives. By contributing to state formation in this way, the inhabitants of Pomio also make claims on what the state should be like. While plantations become governable and state-like spaces, they do not produce simply governable subjects, nor do they produce a uniformly governable territory, but an uneven space in which some places are more governable than others. The inhabitants of Pomio move between these places in their pursuit of different goals.

\section{INTRODUCTION}

In this article I examine the relationship between newly established oil-palm plantations and state formation in Pomio, a remote rural district of East New Britain Province (Papua New Guinea). I focus especially on the kinds of spaces of governance produced by plantations and how this contributes to state formation and territorialisation in Pomio. Pomio District is the largest and most sparsely populated district in East New Britain. The presence of the state and of services in Pomio are minimal (Allen 2009:486), and its inhabitants justly feel marginalised from the wider political and economic structures of the province and the country (e.g. Lattas 2006:136). Due to its its large forested areas and the comparatively small amount of industrial agriculture, in the early 2000 s the district was seen as having potential in terms of the expansion of logging and oil-palm plantations. Because of the limited presence of the state and the perceived opportunities to extract resources and mobilise labour, Pomio can be characterised as a frontier area (e.g. McCarthy 2013:183-184).

I wish to thank Henni Alava, Barbara Andersen, Matti Eräsaari, Colin Filer, Jenni Mölkänen, Sonal Makhija, Liina-Maija Qvist, Heikki Wilenius and several anonymous reviewers for insightful comments on this article. My biggest thanks go to the Wide Bay Mengen who gave me their time and help. The article is based on ethnographic fieldwork conducted in the Wide Bay area on the east coast of New Britain Island in 2011-2012 and 2014, funded by the University of Helsinki Sasakawa Young Leaders Fellowship Fund and by the Academy of Finland (grant 253680). An earlier version of this paper was presented at the European Society for Oceanists 2015 conference in Brussels in the panel "Land, resources and state formation", convened by Colin Filer. 
Some local politicians have decided to exploit the possibilities of this still open frontier. In 2004, the former Member of Parliament (MP) for Pomio initiated a largescale combined logging and oil-palm project called the Ili-Wawas Integrated Rural Development Project. The aim of this 'agroforestry' project was to link Pomio's existing logging roads, which were cleared during logging operations in the 1990s and stop at village of Wawas in the south, to the provincial road network, which extends only to Ili village in the northern part of Pomio, leaving the bulk of the district with no road connections. According to the plan, logging and oil-palm companies would build the road in exchange for logging concessions and land leases. Revenue from the logging whould fund the road and other services and bring immediate income to the state and local landowners. The road connection whould also ease people's access to markets and services. The oil-palm estates whould provide employment opportunities and ensure a continuous company presence, which could then be responsible for the road's maintenance (Wide Bay Investments Ltd. and Tzen Niugini Ltd. 2005:8-9, 12). In a nutshell, the provision of services and infrastructure is shifted on to companies, the state merely providing the legal framework for logging, the leasing of land and labour procurement.

As a part of this project, in 2008 Tzen Niugini, a Malaysian company, established a new oil-palm plantation in the northern Wide Bay area of Pomio on state land, alienated during the colonial period and adjacent land leased for 99 years from the customary landowners. ${ }^{1}$ Many inhabitants of Pomio soon left their villages and took on labour at the new plantation, as did many Mengen speakers with whom I conducted fieldwork in 2011-2012 and again in 2014. This article is based largely on my interviews with Mengen workers and my visit to the plantation. The Wide Bay Mengen areas are located in the south of Wide Bay, some fifty kilometres from the plantation. The rural Wide Bay Mengen are subsistence farmers, who gain a cash income from smallholder cashcropping, migrant labour and sporadically since the 1990s from logging royalties. At the time of writing, Wide Bay Mengen had not leased their lands for oil-palm development, though some of their landowning groups had agreed to logging conducted by the plantation company. Cash-cropping has become more difficult for the Mengen with declining copra prices and because copra-buying ships do not visit the area. In order to sell their produce, the smallholders have to transport it themselves to buying points located far from Mengen areas, thus reducing the profits. With the decline in cash-cropping, migrant wage labour at the Tzen oil-palm plantation has become more lucrative.

As the modern state's power is in important ways enacted and advanced through infrastructure (Chalfin 2010:238, Scott 1998), and as people in Papua New Guinea (PNG) and elsewhere evaluate the legitimacy of the state through the provision of services and infrastructure, ${ }^{2}$ state formation is a central question in relation to the 'agroforestry' pro-

1 For the Special Business and Agriculture Leases under which parts of the Wide Bay plantation lands fall, see Filer (2012).

Anand (2011:545), Balliard and Banks (2003:296), Jansen (2014:253-254) 


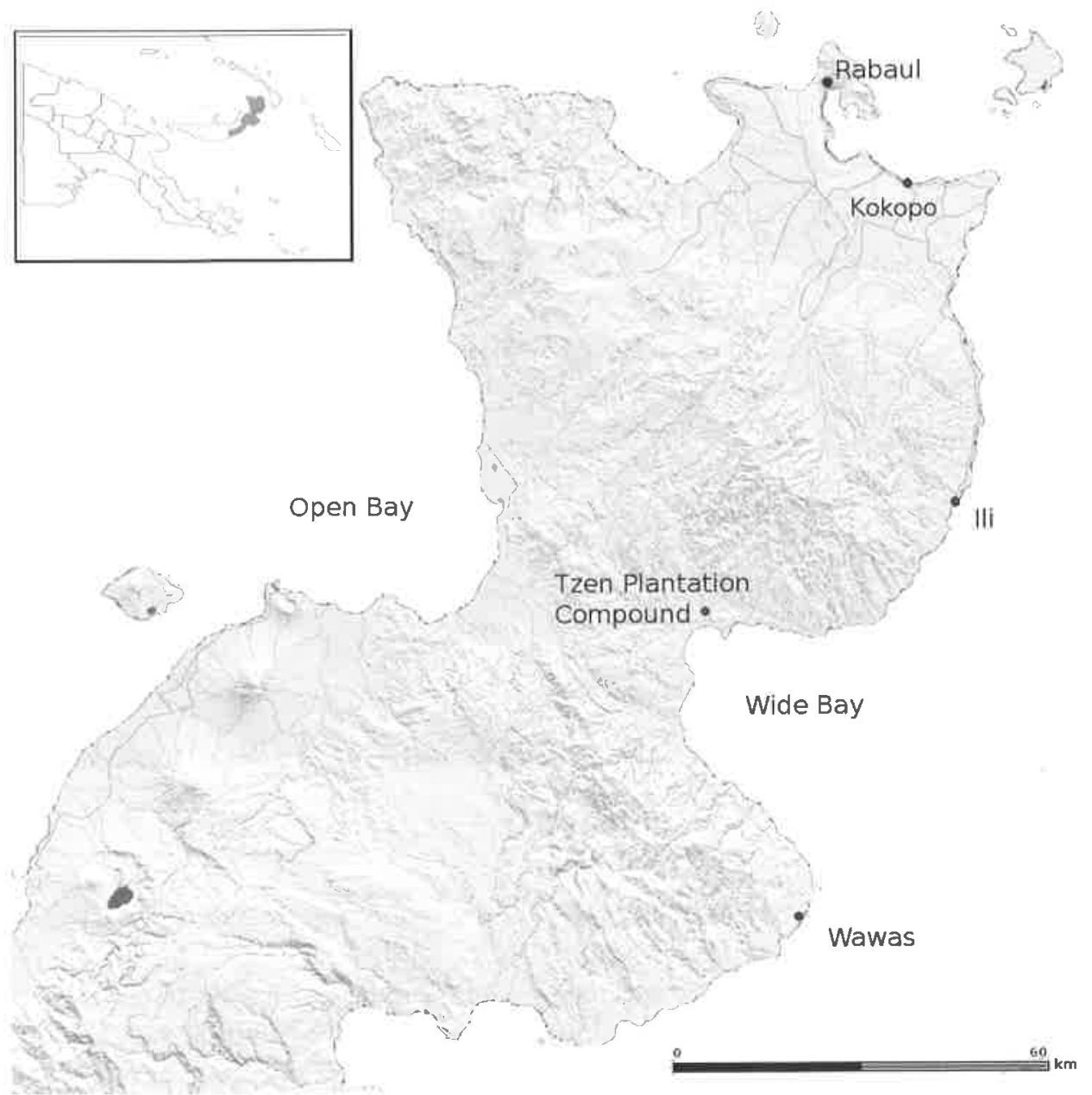

Fig. 1: The Gazelle peninsula and Wide Bay, East New Britain Province (map: T.T.)

ject in Pomio. Moreover, plantations are not only sites of agricultural production and exploitation, but also political projects that create and represent governance through the reordering of the landscape, the mobilisation of labour and capital, and surveillance of the people (Dove 2012:30). In short, they are places where people are controlled and where their activities are prescribed according to the demands of the company and agricultural production. ${ }^{3}$ Historically in Melanesia they have been a means of occupying, 


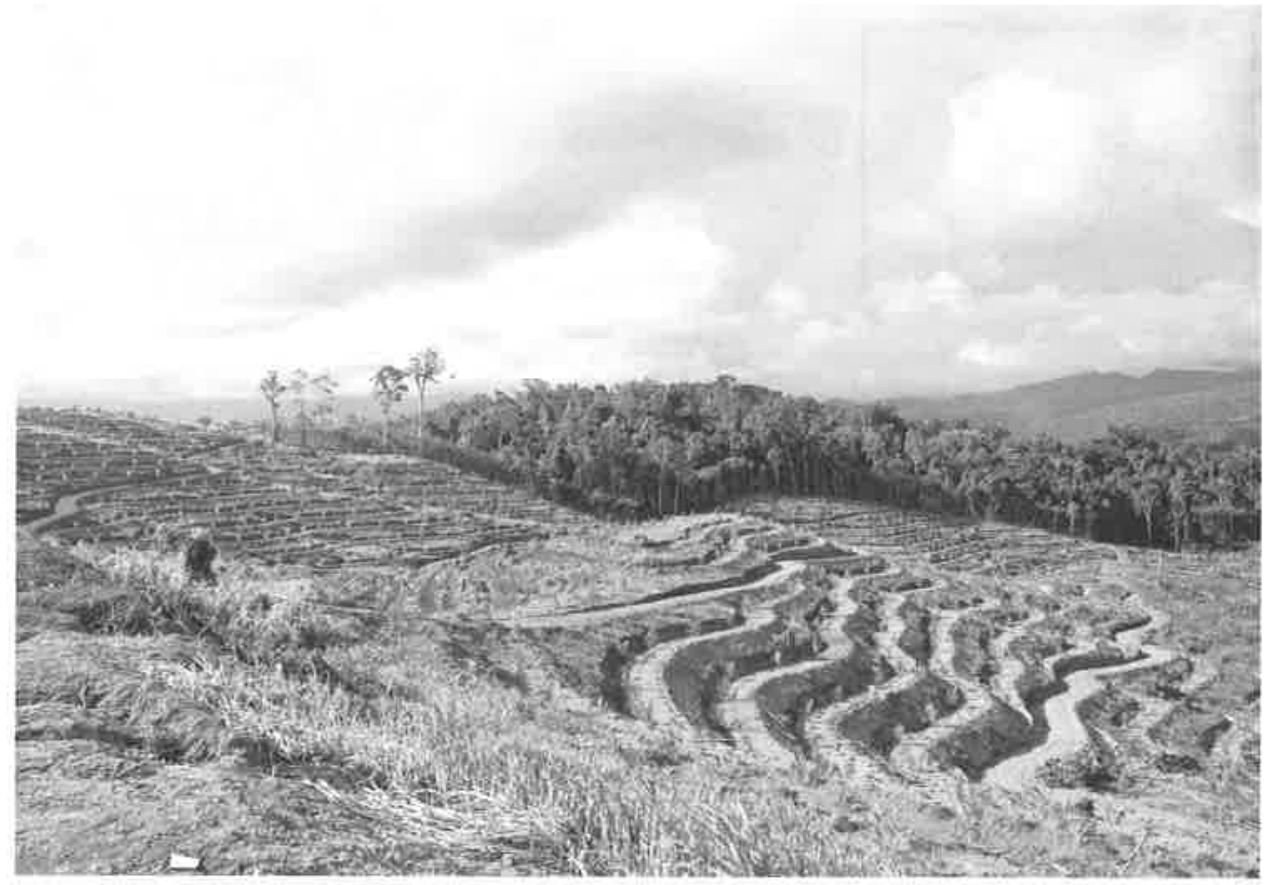

Fig. 2: Oil-palm fields on the Tzen plantation (photos: T.T.)

pacifying and bringing new land into development and of supplementing the work of the colonial administration (Dennis [1981]:219).

Based on recent work in the anthropology of the state, which seeks to understand state power as 'contingent relations and practices rather than isomorphic with any singular state' (Fisher and Timmer 2013:153), I examine the new plantation as one of the 'multiple sites in which state processes and practices are recognizable through their effects' (Trouillot 2001:126). I look at how, in the frontier conditions of Pomio, where the national state is peripheral, the plantation becomes a state-like space and how Mengen workers cope with, contribute to and evade the controlled life on the plantation. In becoming a state-like space, the plantations do not produce a uniformly governable territory and simply governable subjects. Rather, the state is confined to certain places, and people like the Mengen move in and out of them. 
The new plantation is located in the northern part of Wide Bay near the coast on flat terrain that turns increasingly hilly inland. Vast areas of rainforest have been logged, hills have been terraced, and thousands of hectares have been planted with neat rows of oil-palm. In 2012 there was a single compound for the workers. Supervisors lived in company-built barrack-style houses with small cooking huts and shared toilets. Workers lived in shacks they had built themselves from bush material and corrugated iron provided by the company. The manager's house was on a nearby hill over-looking the plantation. The Wide Bay plantation is, like all plantations, a 'legible' environment (Scott 1998:30). It is easily grasped and made to conform to and support the requirements of administration and control (Scott 1998:18, 21, 30). Legibility, as famously defined by James Scott $(1998: 22,30)$, is a tool of governance that allows outsiders to comprehend, administer and control complex situations 'from the centre'. This is achieved by reducing the infinite complexity of reality to those features that the administrators or readers are interested in. Plantations and commercially managed forests are environments where this abstraction and standardisation are taken further: the complexity of reality is not only reduced in representations - actual social life and environments are standardised and abstracted as well (Scott 1998:13-15).

The everyday practices on the plantation show this. In the Wide Bay's plantation nursery, seedlings were marked with the date of planting so that they could be transferred to the field at the right age, supervisors recorded how many palms their groups had planted on a given day, managers knew the exact number of palms in a given block, and so forth. This kind of legibility is obviously crucial for managing a plantation, an environment geared to the commercial production of a single crop. Likewise, and for the same reasons, attempts were made to make social life on the plantation equally legible, standardised and controlled - in other words, it was turned into labour. Each morning started with a roll call, supervisors listed those who turned up for work on that day, workers were divided into sections and groups, each worker performed a specific task, supervisors listed how many times an individual worker performed that task, and so on. Moreover, on the plantation workers were not only listed, but also organised into different sections, like 'planters', 'nursery workers', 'sprayers' and 'mechanics'. Just as plantations create legible environments, people's actions on plantations also need to be made legible and to conform to the requirements of production. ${ }^{4}$

As a result, Dove (2012:30) has likened plantations to Foucauldian panopticons, which are concerned with the 'conduct of conduct'. For the workers, the plantation is thus not only a site of earning meagre but necessary salaries, but also one of controlled labour and regimented living. This was evident in the common notion among Mengen workers that 'Life in the village is free', a phrase used to contrast the plantation with the 


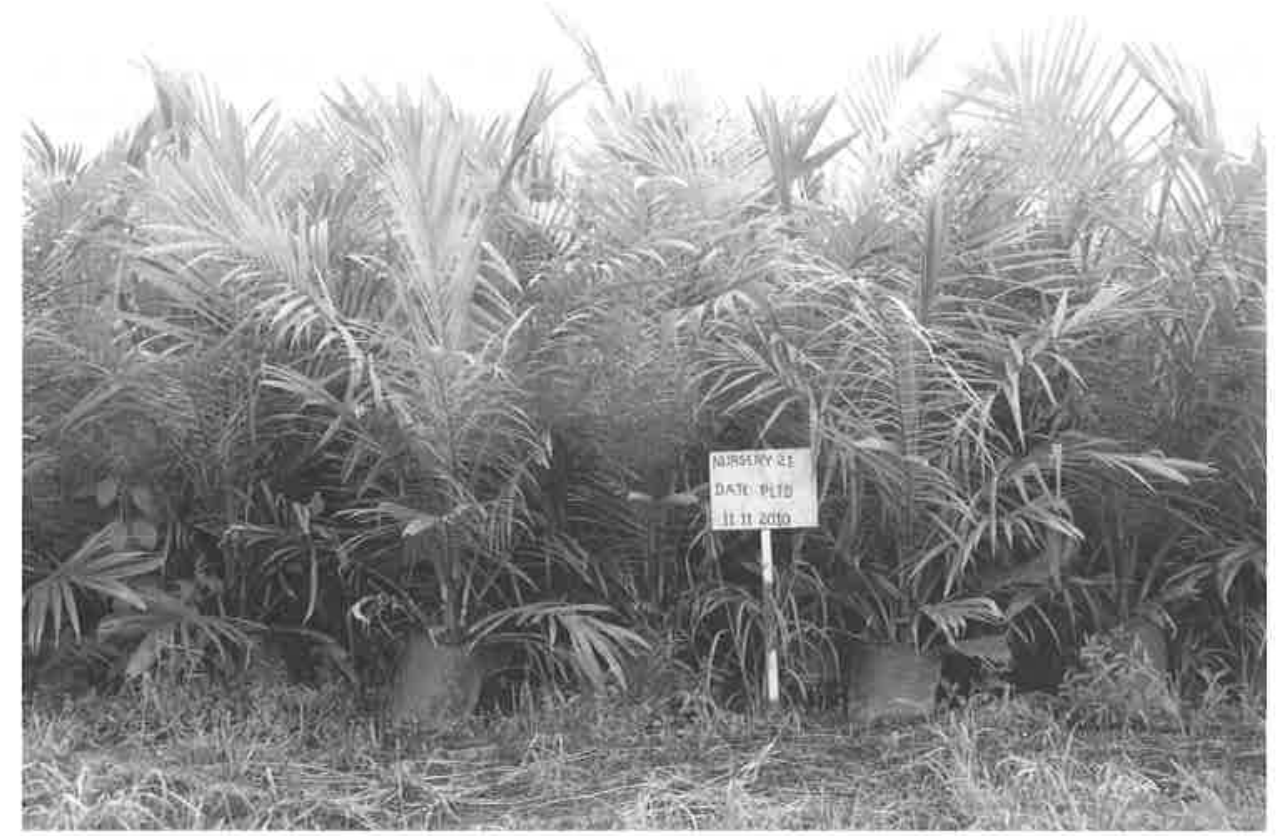

Fig. 3: Legible environments: the oil-palm nursery at the Tzen plantation

village not only as a site of earning and using money, i.e. one dominated by commodity relations, but also as a site of controlled, or alienated, labour. The Mengen workers noted that, whereas in the village people worked as they pleased, on the plantation they had to follow the commands and schedules of others.

In his account, Scott $(1998: 14,262)$ uses the legibility-making practices of scientific forestry and industrial agriculture as parables for statecraft in general. State power relies on the creation of legibility, as it enables control from the centre, as well as standardisation, because local social practices and environments are often too heterogeneous and complex for outsiders to administer (Scott 1998:22, 24, 30). The creation of legibility is crucial for states, but it is not created exclusively by states. Regarding the study of the state, Michel Trouillot (2001:126) has argued that researchers should look beyond national and governmental institutions and focus on the multiple sites in which state processes and practices are recognizable through their effects (see also Lund 2011). The Wide Bay plantation, then, is such a site: it is not a government institution, but it produces so-called state effects and state-like processes.

Along with legibility - one of the 'state-effects' identified by Trouillot (2001:126) the Wide Bay plantations produced others. These effects include the 'isolation effect', namely the production of atomised individual subjects, achieved by means of roll calls 
listing the workers and their individual activities. The allocation of workers to taskbased sections resembles the 'identification effect', or the alignment of these newly created individuals along along new collective lines, which are recognisable to both governing and governed alike (Trouillot 2001:126). This reflects earlier studies of plantations, which - as noted - point out that plantation production hinges not only on cheap land and labour (Dennis [1981]:219), but also on a rigid class division and strict control over the specific tasks of workers (Benson 2008:601, Dove 2012:30).

What is interesting about the Wide Bay case is that the state effects were taken even further. In an interview, a Mengen man working on the plantation mentioned the councillor and his deputies called 'komitis' in Tok Pisin. ${ }^{5}$ The councillor and the deputies are elected officials, who represent their village, or ward council, in the local level government, being the lowest elected officials in the PNG state hierarchy. The councillors and committees are locals who have been elected by their community members, and they are paid an allowance, rather than being fully employed by the state. I asked the man if the plantation had been classed as a government ward, and he replied that it hadn't. The workers elected the plantation councillor and committees, as in a regular ward council, but their allowances were paid by the company. In addition to them, the company had hired a catechist from the Catholic church. Like the councillors, the catechists are not full employees of the mission, but local people trained to lead the dayto-day religious life of the villages, such as holding an abbreviated mass in the absence of a priest, prayer meetings, etc. They too receive an allowance from the mission. The Wide Bay plantation was thus organised along the lines of a government ward without actually being one.

This comes close to Trouillot's (2001:126) fourth state effect, namely spatialisation, or the creation of jurisdiction and boundaries. Even though the plantation has not created a parallel jurisdiction, the government-like order is still noteworthy. It brings to mind Bruce Kapferer's observation that, as states are being run more and more like - imagined - companies, actual corporations are assuming state-like powers (2005:289). The 'corporate states', hybrid forms of governance along the lines of nation states and new managerial techniques, have a minimal interest in regulating populations or territory except for market needs. At the same time as corporations assume more state-like powers, public order is turned into a security issue, which is also privatised, corporatized and turned to a greater extent against the public and citizens, for example when oil-companies hire 'security contractors' or mercenaries to protect their operations. Whereas nation states sought to create order, even if oppressively, corporations are not interested in ordering the mass, but are retreating into enclave forms that are relatively isolated from their surroundings, both socially and spatially. ${ }^{6}$ 
The practice of companies assuming state-like powers seems like an echo from colonial times. The involvement of the inhabitants of New Britain with commodity-relations began in the 1880s with the Pacific labour trade during which Melanesians were recruited to work on sugar plantations in Queensland (Corris 1968). By this time, labour recruiters were also raiding Mengen areas (Panoff 1969:111, also Laufer 1955:32). Germany and Britain partitioned the area, which later become PNG in 1884. Between 1885 and 1899 the German possessions, consisting of New Guinea's north coast, the Bismarck Archipelago and parts of the Solomon Islands, were administered by the Deutsche Neuguinea-Kompagnie (German New Guinea Company [NGC]), a chartered company, which initially sought to speculate in land. From 1885 it had exclusive rights to take possession of 'unowned' land in the colonies or to buy it from the local population. As the NGC administered the German possessions, it could exercise all the authority vested in the Kaiser except for foreign relations and the administration of justice. The German navy, for instance, was obliged to protect 'the Company'. Likewise, when the new Imperial Commissioner attempted to address NGC's wrongdoings in 1891, he was instructed that the administration was supposed to further the Company's interests (Firth 1972:362, $363,368)$.

The Company was soon forced into the plantation economy, as the thousands of settlers to whom it had planned to sell land never arrived (Firth 1976:52). It established plantations on mainland New Guinea, where, however, the local population was unwilling to work on them. As a result, labour was recruited from the Bismarck Archipelago and Solomon Islands, where people were much more familiar with contract labour. Conditions on the mainland plantations were bad, and the annual death rate was a staggering forty percent among the 2,800 labourers who passed through Kokopo between 1887 and 1903 (Firth 1976:52-53). This obviously decreased the attraction of plantation labour, and attacks on recruiters increased, while the number of labourers on the mainland decreased. At the same time the Gazelle peninsula on New Britain became a much more popular destination among labourers from the Islands, as conditions were healthier, and it was closer to home for the workers (Firth 1976:53). The NGC, however, had concentrated its plantation investments on the mainland, where people were less willing to work for them and opportunities for copra trading were fewer than in the Bismarck Archipelago, which produced substantially larger volumes of copra (Dennis [1981]:228). This, and the Company's attempt to engage in what Stewart Firth calls 'imperialism without rule', forced it to relinquish control of the colonies (Firth 1972:374, 377), and in 1899 the Reich took over the administration (Firth 1972:374).

The imperial administration in Germany, and Bismarck in particular, had hoped that the NGC would bear the costs of administration (McKillop and Firth [1981]:9788). This resembles - in spirit at least - the current hope that private companies will provide the services and infrastructure for Pomio that the state is unable, or unwilling, 
to provide. Moreover, the fact that the plantations have been organised along the lines of government wards bears an uncanny resemblance to the colonial era and the role of trading companies in administering colonial possessions, though on a much more limited scale. During most of the colonial era, the British and later Australian administrators also favoured European-owned plantations over peasant production (Dennis [1981]:222,230). The local population was regarded as a source of labour, and rural wages were calculated on the assumption that the workers were single men, which meant that plantation production relied on the villages to reproduce the labour force (Dennis [1981]:232, 244; Gregory 1982:117). In fact, according to Chris Gregory (1982:135), the plantation economy relies on the 'labour frontier', that is, the availability of cheap labour. Over time the first labour frontiers, like New Britain, closed, the local population became smallholders, and the frontier shifted to new areas to be exploited. Finally, with the exhaustion of the last frontier, in 1972 the plantation economy went into crisis (Gregory 1982:131, 136-37, 143, 157).

In New Britain the labour frontier closed with the emergence of smallholder cashcrop production. However, since the 1990s cash-cropping of copra has become harder for the inhabitants of Pomio. The difficulty and costs of transportation limit the returns from smallholding. The crisis of smallholder copra production has in a sense opened up the labour frontier in Pomio once again. People do need money for physical and social reproduction, but the means to get it are few, at least among the Wide Bay Mengen. Likewise, Wide Bay Mengen are able to work at comparatively low wages because many workers plant their own food on the plantation itself or receive it from their home villages. Thus the new plantation still receives subsidies from the surrounding villages. In many ways, then, despite new crops such as oil-palm, the old dynamics are being reproduced on the Wide Bay plantation, which seems to be a general trend in the current agricultural production of food and biofuel crops (Borras, McMichael and Scoones 2010:589).

SELF-MADE ORDER

In light of the long shared history of plantations, colonisation and state formation in Melanesia, the organisation of the Wide Bay plantation along government lines is perhaps less surprising than it initially seemed to me. What surprised me even more was that the workers claimed to have suggested this form of organisation themselves. According to workers I interviewed, the security guard was hired by the company from the start, but employing catechists and elected officials had been suggested by the workers, and the management had agreed to this. One worker, who had risen to a higher position in the company, said the following in an interview I conducted with him in his home village: 
We [pay them] ourselves. The police [security guard]. It's not the state who pays their salaries. The catechist as well. They became sort of employees of the company. The management pays their salaries. But they work as the government officials do. And now the government is aware of this. The President [of East Pomio Local Level Government] and the MP [of Pomio] came to see the plantation. They were surprised. Because other companies do not have catechists, councillors and komitis. They've got police and security. But not the others. [...] Their minds clicked when they saw this. ${ }^{7}$

Noteworthy in the quote above is the pride with which the worker describes the reactions of the state officials. This is therefore not simply a case of a company assuming state-like powers on a frontier or the 'top-down' production of state effects. On the contrary, this seems to be state formation from below.

The example case of the workers themselves proposing that the plantation on which they work should be organised along the lines of a government ward resembles the case of Bugis settlers in rural Kalimantan - a place where the state is equally peripheral in terms of services (Timmer 2010:706, 711). Jaap Timmer shows how people in remote areas of Kalimantan have adopted state-like instruments in order to 'be seen like a state', i.e. to have their sovereignty recognised by the state $(2010: 705,711)$. Local elites especially have emulated the state's legal culture so that local land-tenure arrangements may potentially be recognised by the state and in order to present (and legitimate) patron-client relations (Timmer 2010:704-705). According to Timmer (2010:705), the practice of people adopting state-like forms shows not so much their willingness to become subjects of the state as their wish to be seen like one, because of the 'suggestion of sovereignty' that accompanies state-like formations.

Similar interpretations have been made of people in rural Melanesia adopting and subverting institutions like churches or schools for the purposes of their own moral economy (Barker 1996:211), using institutions synoptically (Carrier and Carrier 1989:17), or creating localised and alternative forms of government through which they engage with the state and politics (Lattas 2006). These are all valuable and accurate analyses that have shed light on politics and economies in Melanesia. Yet, as Thiago Oppermann (2015:201) has noted, interpretations of Melanesian adoptions of bureaucracies and state forms as 'mimicry' or 'mimesis', while often warranted, place the state as always external to Melanesian societies. If taken too much for granted, notions of mimesis may obscure our view of cases where the state is 'thoroughly enmeshed with local political organization' and where locals are not mimicking the state, but locally building it, as in Op-

'Mipela yet. Police. Govaman i no baim. Katiket tu. Ol i kamap olsem ol wokman bilong kampani. Management i baim. Tasol ol i wokim ol wok olsem how ol lain bilong govaman i wok. Nau govaman tu i luksave. President na memba i go insait tu na lukluk. Ol i kirap nogut ya. Bikos long ol kampani i nogat katiket na inogat ol councillar na komiti. I gat police na security. Tasol ol narapela nogat. [...] Tingting bilong ol i click, taim ol i lukin' (man, 39 years; November 12, 2011; interview recorded by author, name not disclosed to protect anonynity of interviewee). 
permann's analysis of the local enforcement of payments of school fees in Bougainville (2015:210, 215).

Stef Jansen (2014) comes close to Oppermann in his constructive critique of anthropology's so-called 'libertarian paradigm', which has presented the state as an imposition in a two-fold way: first by unmasking modern statecraft's top-down claims to enlightened progress, and secondly by documenting people's resilience and opposition to that statecraft (Jansen 2014:239). Jansen has analysed bottom-up organisation and the making of state infrastructure in Bosnia during the civil war. One example of this was the so-called 'staircase schools', which people organised after schools had been closed because of the war. An important part of the staircase schools was to create a 'normal life' and its rhythms in a situation that was anything but normal, as well as encourage people's pragmatic orientation towards a future time of peace (Jansen 2014:244-249). This was clearly a bottom-up form of organisation and something people took pride in. It could be easily explained by means of a 'libertarian narrative' as representing opposition to top-down policies and as an example of mêtis, the bricoleur-like practical knowledge and skill described by Scott $(1998: 7,313)$, or what savvy people on the ground use to navigate their lives. In Scott's (1998) account, the use of mêtis is often at odds with the ways the state sees and works. However, people in Bosnia ran these schools out of necessity and explicitly sought to call the state into being, or at least to restore aspects of it (Jansen 2014:252-254).

Jansen's and Oppermann's notions are central to the case of Wide Bay. The experienced workers who organised the plantation along government lines certainly empowered themselves by showing that they could influence the development of the plantation and that their suggestions were taken seriously by the management. It is no surprise that workers with prior experience of oil-palm labour should rise in the company hierarchy. This happens in other institutions too. For example, Adam Reed (2003:39) notes how, in the early colonial era, former prisoners often became prison warders or members of the village constabulary themselves. Labourers and convicts, those first exposed to state institutions, often became the first representatives of the state in rural or frontier areas. The ward council-type of organisation has certainly also emerged in the shadow of the state (Timmer 2010:710). As the man quoted above noted, the newly established officials worked like their government counterparts, but without actually being in the state hierarchy. However, the workers who proposed the ward-type of organisation were also proud of having impressed actual state officials with their initiative. Those officials were probably genuinely surprised; after all, the combined logging and plantation project was their attempt to increase state coverage in Pomio. Organising the plantation along the lines of a ward council probably exceeded their wildest expectations.

Here, then, two processes of state-making converged. By enacting an idealised state order - the ward council with its catechists and elected representatives - the workers were making claims on what the state s h o u l d be like (see Timmer 2010:707, 711). In the Wide Bay case, the term 'enactment' is more appropriate than 'emulation' or 
'mimicry', which refer to a form that has been copied but without the same content (Oppermann 2015:200). Indeed, the workers in Wide Bay well knew how the state worked or was supposed to work, and they enacted that kind of order. To all intents and purposes this is state order, not a copy, though the state is being built by what Oppermann calls p a r a st at al groups $(2015: 199,211)$. In PNG these comprise a large number of more or less formal groups ranging from so-called civil society, business and kin groups to formalised informal courts, village governments and bureaucratised 'traditional' authorities. They are loosely integrated into existing bureaucracies, but not free from the state and certainly not antagonistic to it. They are sometimes made by the state, as in the case of village courts or school boards, and sometimes come to life on their own (Oppermann 2015:211), as on the Wide Bay plantation.

These parastatal groups are not an example of mimicry, but a continuation of an actually existing state. They are part of the PNG state ideology, which valorises 'the local', sometimes to the point where institutions like village courts bear a substantial organisational burden and on whose work the state relies, but which the state supports only scantily (Oppermann 2015:211, also Lattas 2011). At other times these parastatal groups become a corporatized form of governance, as in the case of landowner companies (Lattas 2011:90) or on the plantations.

\section{UNEVEN TERRITORY}

The outcome seems to be a neatly organised plantation. In 2011 the security guard of the plantation slashed a young male worker with his bush knife during an argument. This angered the worker's friends, who forced the security guard to flee from the plantation. At the time of my visit in 2012 he was still gone, with only the stoned windows of his apartment as a reminder of what had happened. Nonetheless people kept working on the plantation as usual and without disturbances. Yet, while the workers have made the plantation conform to an idealised state order and enact it even when attacked by the security personnel, the plantation has not simply produced model subjects of the state.

In 2014, during a follow-up visit to Wide Bay, I heard that men from a particular Mengen village had all deserted the plantation. Due to grievances over local electoral politics, people from another Mengen village had accused them of sorcery and managed to get the police to the village, largely because of their close connections with the provincial administration. People from the accused village fled into the rainforest where they hid for several weeks until the police left the area empty-handed. The men from this village who were working on the plantation felt like too easy targets for the police in this 'legible environment'. They all deserted the plantation and stayed in the village after the police had returned. This shows that legibility is a matter of degree and that territorialisation in Pomio is uneven. Plantations, as quasi-state spaces, are extremely 
legible environments, places where the police routinely stay on their way to the rural areas.

Villages in Wide Bay are legible environments as well. Missionaries and the colonial government encouraged people to leave their smaller and more dispersed hamlets and move to hamlets near the coast and along the main trails. By the 1970s the Wide Bay Mengen had abandoned their inland settlements and moved to the coast. Yet, because of the lack of a road connection, even contemporary coastal villages are hard and expensive to reach from administrative centres, as travelling is done by boats. The police come to these villages only if their travel expenses are paid. In many cases, the police come to Pomio when requested to do so by logging companies operating in the area (also Lattas 2011). While harder to reach, the villages are still 'legible' to outsiders, as the example of people fleeing into the forest shows. For the Wide Bay Mengen, the inland forest is dotted with places of significance, like abandoned settlements, and a network of trails, both used and forgotten. For someone who has not lived in the area it is a confusing landscape, where traveling is laborious and one is likely to get lost. When rural people want to avoid the violent arm of the state, they move back into the forest.

However, female workers from the village in question stayed on the plantation. This is because electoral politics are a nearly exclusively male sphere, and sorcery accusations are made only against men. Places and infrastructures are materialisations of different social relations and the historical processes that have created them, being one of the media through which these relations and processes become manifest (Anand 2011, Stasch 2013). As a result, they are rarely neutral. For example, in the Eastern Highlands of PNG, women's access to health services is affected by the relationships of their husband's kin: if an aid-post is located on the land of a group that is in conflict with a woman's husband, the woman cannot simply go to the aid-post (West 2006:95). Similarly, for the Mengen men from the accused village the plantation became an unsafe place because the close relations with their accusers and the state administration became manifest through the legible space of the plantation, where the police can operate more easily.

\section{CONCLUSION}

The Ili-Wawas 'agroforestry' project was set up by local politicians to overcome the marginality of the Pomio region. Initiated in 2004, the road connection to the provincial capital was finally established in July 2015. It remains to be seen how the road connection transforms the district. For local politicians, Pomio district was like a frontier, where the presence of the national and provincial state and its services were weak. To this end, logging and plantation companies were contracted to build the road and fund services in exchange for logging concessions and land for plantations. For the 
companies, the frontier was a place with seemingly unused resources and cheap labour. Indeed, the ability to lease land for up to 99 years from the customary owners and the demise of cash-cropping had re-opened the land and labour frontier in Pomio.

As the companies were given a prominent role in delivering infrastructure and services previously associated with the national state, I set out to examine what kinds of spaces of governance and territorialisation are produced by plantations in Pomio. Plantations have historically been tools of governance and means of occupying, pacifying and bringing new land into development and supplementing the work of colonial administration, as Maxine Dennis ([19817:244) has put it. Important as road infrastructure is in expanding the reach of state institutions (Ferguson 1994, Tammisto 2010), this was not the only 'state effect' ('Trouillot) they had. The new plantation has itself become a state-like and governed place. ${ }^{8}$ In addition to the more predictable effects, such as the re-organisation and control of people, that are associated with plantation production, the plantation became organised like a government ward with its elected representatives, without actually being one. Even more striking is the fact that this organisation was not a top-down imposition, but an initiative of experienced plantation workers.

On the Wide Bay plantation several processes of creating a state-like order or even the state, converged. While the company was engaged in organising the plantation 'from the top down' according to the needs of production, the Mengen workers organised it from the bottom up to resemble ideal forms of state order or village-level government. These workers, many of whom had considerable experience of plantation labour from West New Britain and elsewhere, had risen in the company hierarchy, and they were thus able to empower themselves by creating organisational structures through which to interact with the management. They created state-like forms, not so much to legitimise existing inequalities, like the Bugis elites in Timmer's account, but in order to lay claims on what the state should be like (cf. Timmer 2010:707, 711). They did so by out-doing the state, to borrow Oppermann's (2015:215) apt expression. The workers did not just want to be seen like a state, but created on their own account state structures where these were absent. As the workers were proud that state officials were positively surprised, it seems that they created these structures so that the state could adopt them (Timmer 2010:704) - in anticipation of the state, so to say.

One reason for this may be that, while the companies produce certain kinds of 'state-effects', their interests are more limited. The state-like aspects of plantation production are, as noted, suited above all to the needs of production. Like the German colonial administration, which hoped that the ventures of the NGC would fund the administration of the colonies (McKillop and Firth [1981]:87-88), the local politicians of Pomio hoped that the companies would fund the services and infrastructure that Pomio lacks. In the end, governance via a company proxy did not work out and the imperial administration had to take over, for good and for worse. Rather than creating a

See, e.g., Benson (2008), Dennis ([1981]:219) and Dove (2012:23, 30). 
uniformly governable territory, present-day companies create an uneven space in which some places are more governable than others. Indeed, plantations seem to benefit from this uneven development which maintains frontier conditions (Gregory 1982:129). This is in line with James Ferguson's (2005:378-380) observation that capital, particularly of the extractive type, often creates highly selective territorialisation, enclaves and 'patchy' governance.

While the plantation has become a state-like place, the Ili-Wawas project has not simply produced governable subjects. When Mengen workers become fed up with controlled labour, feel oppressed or are indeed threatened by the violent arm of the state, they leave the plantation and return to their villages - or go and hide in the forest. While experienced workers make claims on the state by building it locally on the plantation, others, often those at the bottom of the company hierarchy, flee it. Different places are associated with and materialise different kinds of social relations and historical processes (Stasch 2013:555). As Rupert Stasch has noted, some spatial formations, or places, embody multiple social principles and historical processes (2013:555). They are thus loaded with different meanings, so to say, and as spatial formations they can be used by people to mediate between the different meanings.

The integrated logging and plantation project has created an uneven space with differently 'loaded' places, some of which are more legible and governable than others. It seems that people like the Mengen are taking as much advantage as they can of this situation and are moving between the different places to live out and shun the different relations associated with them (Stasch 2013:565). The Mengen have a long history of creating their own alternatives to the state (Lattas 2006). As the above discussion shows, they are also building up the state locally. It seems that, in the frontier context of Pomio, the state has indeed become literally localised, confined to certain locations, but not to others. In taking advantage of this difficult situation, the Mengen move in and out of the state according to their needs.

\section{REFERENCES}

ALLEN, Bryant

2009 "Agricultural development, policies and governance", in: Michael Bourke and Tracy Harwood (eds.), Food and agriculture in Papua New Guinea, 425-488. Canberra: Australian National University 
BALLARD, Chris and Glenn BANKS

2003 "Resource wars: the anthropology of mining", Annual Review of Anthropology 32(1):287-313

BARKER, John

1996 "Village inventions: historical variations upon a regional theme in Uiaku, Papua New Guinea”, Oceania 66(3):211-229

BENSON, Peter

2008 "El Campo: faciality and structural violence in farm labor camps", Cultural Anthropology 23(4):589-629

BERNSTEIN, Henry and Michael PITT

1974 "Plantations and modes of exploitation", Journal of Peasant Studies 1(4):514-526

BORRAS, Saturnino M., Philip McMICHAEL and Ian SCOONES

2010 "The politics of biofuels, land and agrarian change: editors' introduction", Journal of Peasant Studies 37(4):575-592

CARRIER, James G, and Achsah H. CARRIER

1989 Wage, trade and exchange in Melanesia: a Manus society in the modern state. Berkeley: University of California Press

CHALFIN, Brenda

2010 Neoliberal frontiers: an ethnography of sovereignty in West Africa. Chicago and London: The University of Chicago Press

CORRIS, Peter

1968 "'Blackbirding' in New Guinea waters, 1883-84: an episode in the Queensland labour trade", The Journal of Pacific History 3:85-105

DENNIS, Maxine

[1981] "Plantations", in: Donald Denoon and Catherine Snowden (eds.), A time to plant and a time to uproot: a bistory of agriculture in Papua New Guinea, 219-248. [Papua New Guinea:] Institute for Papua New Guinea Studies

DOVE, Michael R.

2012 The banana tree at the gate: a bistory of marginal peoples and global markets in Borneo. New Haven: Yale University Press

FERGUSON, James

1994 The anti-politics machine: 'development', depoliticization and bureaucratic power in Lesotho. Minneapolis: University of Minnesota Press

2005 "Seeing like an oil company: space, security and global capital in neoliberal Africa", American Anthropologist 107(3):377-382 
FILER, Colin

2012 "Why green grabs don't work in Papua New Guinea", Journal of Peasant Studies 39(2):599-617

FIRTH, Stewart

1972 "The New Guinea Company, 1885-1899: a case of unprofitable imperialism", Historical Studies 15(59):361-377

1976 "The transformation of the labour trade in German New Guinea, 1899-1914", The Journal of Pacific History 11(1):51-65

FISHER, Daniel and Jaap TIMMER

2013 "Preface: becoming like the state", Oceania 83(3):153-157

GREGORY, Chris

1982 Gifts and commodities. London: Academic Press

JANSEN, Stef

2014 "Hope for/against the state: gridding in a besieged Sarajevo suburb", Ethnos 79(2):238260

KAPFERER, Bruce

2005 "New formations of power, the oligarchic-corporate state and anthropological ideological discourse", Anthropological Theory 5(3):285-299

LATTAS, Andrew

2006 "The utopian promise of government", Journal of the Royal Antbropological Institute 12(1):129-150

2011 "Logging, violence and pleasure: neoliberalism, civil society and corporate governance in West New Britain", Oceania 81(1):88-107

LAUFER, Carl

1955 "Aus Geschichte und Religion der Sulka", Antbropos 50(1-3):32-64

LUND, Christian

2011 "Fragmented sovereignty: land reform and dispossession in Laos", Journal of Peasant Siudies 38(4):885-905

McCARTHY, John

2013 "Tenure and transformation in Central Kalimantan: after the 'Million Hectare' project", in: Lucas Anton and Carol Warren (eds.), Land for the people: the state and agrarian conflict in Indonesia, 183-214. Athens: Ohio University Press

McKILLOP, Robert and Stewart FIRTH

[1981] "Foreign intrusion: the first fifty years", in: Donald Denoon and Catherine Snowden (eds.), A time to plant and a time to uproot: a bistory of agriculture in Papua New Guinea, 85-104. [Papua New Guinea]: Institute for Papua New Guinea Studies 
OPPERMANN, Thiago Cintra

2015 "Fake it until you make it: searching for mimesis in Buka village politics", Oceania 85(2):199-218

PANOFF, Michel

1969 "An experiment in inter-tribal contacts: the Maenge labourers on European plantations 1915-42”, The Journal of Pacific History 4(1):111-125

REED, Adam

2003 Papua New Guinea's last place: experiences of constraint in a postcolonial prison. New York: Berghahn Books

SCOT'T, James

1998 Seeing like a state: how certain schemes to improve the buman condition have failed. New Haven: Yale University Press

STASCH, Rupert

2013 "The poetics of village space when villages are new: settlement form as history making in Papua, Indonesia", American Etbnologist 40(3):555-570

TAMMISTO, 'Tuomas

2010 "Strengthening the state: logging and neoliberal politics in East New Britain, Papua New Guinea", Suomen Antropologi: Journal of the Finnish Antbropological Society 35(1):43-59

TIMMER, Jaap

2010 "Being seen like the state: emulations of legal culture in customary labor and land tenure arrangements in East Kalimantan, Indonesia", American Etbnologist 37(4):703-712

TROUILLOT, Michel-Rolph

2001 "The anthropology of the state in the age of globalization: close encounters of the deceptive kind", Current Antbropology 42(1):125-138

WEST, Paige

2006 Conservation is our government now: the politics of ecology in Papua New Guinea. Durham: Duke University Press

WIDE BAY INVESTMENTS LTD, and TZEN NIUGINI LTD.

2005 Environment impact statement for Ili-Wawas Integrated Rural Development Project, East New Britain Province. Unpublished document. https://archive.org/details/Ili-wawasIntegratedRuralDevelopmentProjectEis2005 [accessed 1 February 2016] 